\title{
Qualitative Perfusion Assessment of Myocardial Viability Study in Patients Who Cannot Stop Long-acting Nitrate: Serial Case Reports
} Penilaian Perfusi Kualitatif Studi Viabilitas Miokard pada Pasien yang Tidak Dapat Menghentikan Long-acting Nitrate: Laporan Kasus Serial

\author{
Erwin A Soeriadi ${ }^{*}$, Badai B Tiksnadi ${ }^{2}$, Junan Imaniar ${ }^{1}$, Hendra Budiawan ${ }^{1}$, A \\ Hussein S Kartamihardja ${ }^{1}$ \\ ${ }^{1}$ Department of Nuclear Medicine and Molecular Theragnostic Dr. Hasan Sadikin \\ General Hospital/Faculty of Medicine Universitas Padjadjaran Indonesia \\ ${ }^{2}$ Department of Cardiology and Vascular Medicine, Dr. Hasan Sadikin General \\ Hospital/ Faculty of Medicine Universitas Padjadjaran Indonesia \\ RSUP Dr. Hasan Sadikin/Fakultas Kedokteran Universitas Padjadjaran \\ Jl. Pasteur 38, Bandung \\ *Corresponding author \\ E-mail: r.erwin@unpad.ac.id
}

Received: February 24, 2021

Accepted: July 17, 2021

\begin{abstract}
The information of myocardial viability status is important to decide the management of $C A D$. Myocardial viability study (VS) with short-acting nitrate (SAN)-added is recommended to perform inpatient with CAD before revascularization therapy. This study aims to determine whether there are differences in the perfusion results of myocardial viability studies with Longacting nitrate (LAN) and those with added SAN. Three patients with CAD were referred to our department for myocardial VS to determine the treatment choice. Long-acting nitrate (LAN) was consumed regularly every day and not allowed to be stopped due to the symptomatic chest pain. Patients underwent two myocardial perfusion VS, the first study with continuing the daily routine LAN only and the second one with SAN-added to the daily routine LAN. VS was analyzed qualitatively. The result of this study, no significant perfusion difference between LAN treatment only and SAN-added studies, it is possible the LAN regular dose alone is sufficient to create a vasodilating effect on the arteries without the need for addition of SAN. Conclusion, patients who take LAN routinely, VS might be performed without the need to take additional vasodilator prior to radiopharmaceutical injection.
\end{abstract}

Keywords: coronary artery disease; myocardial perfusion imaging; revascularization therapy; viability study

\begin{abstract}
Abstrak
Informasi status viabilitas miokard penting dalam menentukan penatalaksanaan penyakit arteri koroner (PAK). Studi viabilitas miokard dengan penambahan short-acting nitrate (SAN) direkomendasikan untuk dilakukan pada pasien dengan PAK sebelum terapi revaskularisasi. Tujuan dari studi ini adalah untuk mengetahui perbedaan hasil perfusi dari studi viabilitas miokard dengan Long-acting nitrate (LAN) dan yang ditambahkan SAN. Tiga pasien dengan PAK dirujuk ke departemen kami untuk studi viabilitas miokard dalam menentukan pilihan terapi yang akan dilakukan. LAN dikonsumsi secara teratur setiap hari dan tidak boleh dihentikan karena adanya
\end{abstract}


gejala nyeri dada berulang. Pasien menjalani dua studi viabilitas perfusi miokard, studi pertama dengan tetap melanjutkan LAN rutin harian saja dan yang kedua dengan tambahan SAN serta LAN rutin harian tetap dilanjutkan. Viabilitas miokard dianalisis secara kualitatif. Hasil yang didapat pada laporan kasus ini, tidak ada perbedaan perfusi yang signifikan antara studi viabilitas miokard dengan LAN saja dan yang ditambahkan SAN, ada kemungkinan bahwa dosis harian LAN sudah cukup untuk menciptakan efek vasodilatasi pada arteri tanpa perlu penambahan SAN. Simpulan, pada pasien yang mengkonsumsi LAN secara rutin, viabilitas dapat dilakukan tanpa perlu mengkonsumsi vasodilator tambahan sebelum dilakukan injeksi radiofarmaka.

Kata kunci: pencitraan perfusi miokard; penyakit arteri koroner; studi viabilitas; terapi revaskularisasi

\section{Introduction}

A history of myocardial infarction decreased left ventricular function and the information on myocardial viability studies (VS) has a significant prognostic value in patients with chronic coronary artery disease (CCAD). The assessment of these cardiac disorders plays an important role in the management of coronary arterial disease (CAD), particularly in determining therapy when revascularization therapy (RT) is considered the first treatment option. The viability study concept is used to explain the improvement of left ventricle function, which left ventricle dysfunction in the viable myocardial is much better than non-viable myocardial. ${ }^{1}$

Myocardial perfusion imaging (MPI) is one of the modalities frequently used to diagnose coronary artery disease. Currently, the aim of the MPI examination is not only for diagnosis, but also to determine risk stratification, prognostic value, determination of treatment options, and as a modality for viability studies in patients with CCAD. VS using radionuclides such as Thallium201 (TI-201) has been used to determine myocardial viability, however, due to radiation safety concerns, many centers are using the Technetium-99m (Tc-99m) sestamibi and tetrofosmin combined with nitrate administration is an alternative procedure that is widely used for myocardial viability studies. ${ }^{2}$

Viability studies assessment with nuclear medicine techniques is an efficient, costeffective, non-invasive modality and is needed to determine therapy decisions, especially if RT is the primary option. A viability study with short-acting nitrate added has been widely carried out since it was introduced for the detection of myocardial viability. The objective of short-acting nitrate-added is to dilate the arterial lumen and increase myocardial blood flow in severe hypoperfused myocardial segments. If the myocardial segments showed perfusion improvement following short-acting nitrate-added, it means that the myocardial segments are viable. In the 


\section{Serial Case Reports}

clinical setting of CAD, revascularization therapy is a useful option and provides more information when using short-acting nitrate added. ${ }^{3}$

In our hospital, patients are referred to the Department of Nuclear Medicine and Molecular Theragnostic Dr. Hasan Sadikin General Hospital / Faculty of Medicine Universitas Padjadjaran, for VS before RT, most of the patients under routine long-acting nitrates treatment or short-acting nitrates when a patient develops cardiac chest pain. Each patient should discontinue nitrate consumption for at least 1 day before the short-acting nitrate-added VS procedure. Viability studies imaging was taken using a two-day protocol. The first procedure was done without short-acting nitrate-added, and the second procedure was done with short-acting nitrate-added. Two images taken from both procedures were compared to each other to see uptake discrepancy.

In these cases, the evaluation of myocardial viability in patients who routinely took longacting nitrates/nitroglycerin trinitrate was performed without short-acting nitrateadded/Isosorbide dinitrate (ISDN) on the first day and with short-acting nitrate-added/ISDN on the second day. Tc-99m sestamibi with total doses of $24 \mathrm{mCi}$ was injected intravenously. Initial blood pressure was measured, and an intravenous (IV) line is attached in patients during a shortacting nitrate-added examination to anticipate an emergency condition. Patients were given shortacting nitrate/ISDN $10 \mathrm{mg}$ sublingually, then Tc-99m sestamibi was injected 15-20 minutes following sublingual short-acting nitrate administration. Heart rate and blood pressure were measured at baseline and 10-, 20-, 30-, and 60-minutes following nitrate administration. The images were taken 45-60 minutes after injection of radiopharmaceutical.

We reported three cases of patients who were unable to discontinue long-acting nitrates due to clinical considerations, but VS was still performed with and without short-acting nitrateadded, and then the images taken from the two procedures were compared.

\section{Case Presentation}

\section{Patient I}

A 65-year-old male who routinely exercises was diagnosed with anterior wall STEMI. During sports activities, he has no experience a heart attack or shortness of breath. At the time of examination, the general condition was good, with full of awareness. Physical examination showed blood pressure 100/60 $\mathrm{mmHg}$, heart rate: 75 beats per minute, breathing 20 beats per 


\section{Serial Case Reports}

minute, regular heart rhythm S1-S2, there was no murmur and gallop rhythm as well; normal pulmonary vesicular breath sound.

Table 1. Patient's Characteristics. Medical History, Risk Factor, and Clinical Characteristics of CAD Patients for The VS Study.

\begin{tabular}{llll}
\hline Variable & Patient I & Patient II & Patient III \\
\hline Sex & Male & Male & Male \\
Age (years) & 65 & 55 & 40 \\
CAD history & 2 months & 9 years & 1 year \\
Blood pressure & $100 / 60 \mathrm{mmHg}$ & $100 / 60 \mathrm{mmHg}$ & $110 / 80 \mathrm{mmHg}$ \\
Coronary Stenosis & & & \\
$\quad$ LAD & Yes & Yes & Yes \\
$\quad$ LCX & Yes & Yes & Yes \\
$\quad$ RCA & Yes & Yes & Yes \\
Risk Factor & & & \\
$-\quad$ Hypertension & No & Yes & No \\
$-\quad$ Hypercholesterolemia & No & No & Yes \\
$-\quad$ Diabetes Mellitus & No & No & Yes \\
$-\quad$ Smoking & No & Yes & Yes \\
$-\quad$ Stress & No & No & No \\
Medical Therapy & & & \\
$-\quad$ Antiplatelet & Yes & Yes & Yes \\
$-\quad$ ACE-I & No & Yes & No \\
$-\quad$ B-Blocker & Yes & Yes & Yes \\
$-\quad$ Diuretics & No & No & Yes \\
$-\quad$ Short-Acting Insulin & No & No & Yes \\
$-\quad$ Statin & Yes & No & Yes \\
$-\quad$ Nitrate & Yes & Yes & Yes \\
\hline
\end{tabular}

During the administration of $10 \mathrm{mg}$ short-acting nitrate/ISDN sublingual, blood pressure was monitored every 10 minutes. The patient has experienced blood pressure drops to 60/40 $\mathrm{mmHg}$, while he waits for the imaging procedure, $250 \mathrm{ml}$ of normal saline was given according to the cardiologist's recommendation. The side effect of short-acting nitrate-added in this patient was hypotension and recovered by infusion of normal saline.

The results showed there was no significant difference in perfusion defects between the two images in the evaluation of myocardial viability. (Figure 1). 


\section{Serial Case Reports}
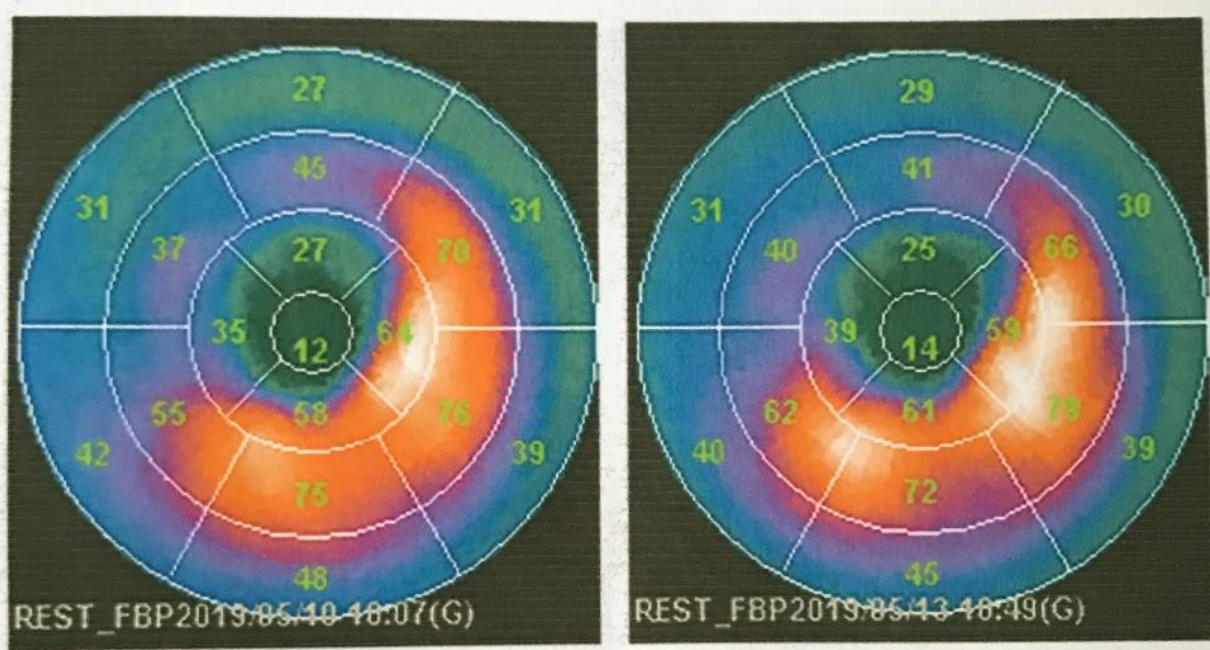

$\mathbf{A}$

B

Figure 1. Viability study (VS) images in the patient under routine long-acting nitrates/ nitroglyceryl trinitrate treatment. A: With short-acting nitrate/ISDN $10 \mathrm{mg}$ sublingually, B: Without SAN-added.

\section{Patient II}

A 55-years-old male, with a history of post-PCI due to 3VD of CAD. He complained of recurrent chest pain that was unrelated to physical activity and no shortness of breath. At the time of examination, the general condition was good with full of awareness. Physical examination showed blood pressure 100/60 mmHg, heart rate: 66 beats per minute, breathing 20 beats per minute, regular heart rhythm S1-S2, there was no murmur and gallop rhythm as well; normal pulmonary vesicular breath sound.

During the administration of $10 \mathrm{mg}$ short-acting nitrate/ISDN sublingual, blood pressure was monitored every 10 minutes. The patient has experienced dizziness and blood pressure drops to $60 / 40 \mathrm{mmHg}$. while he waits for the imaging procedure, $250 \mathrm{ml}$ of normal saline was given according to the cardiologist's recommendation. The side effect of short-acting nitrate-added in this patient was hypotension and recovered by infusion of normal saline.

The results showed there was no significant difference in perfusion defects between the two images in the evaluation of myocardial viability. (Figure 2). 


\section{Serial Case Reports}
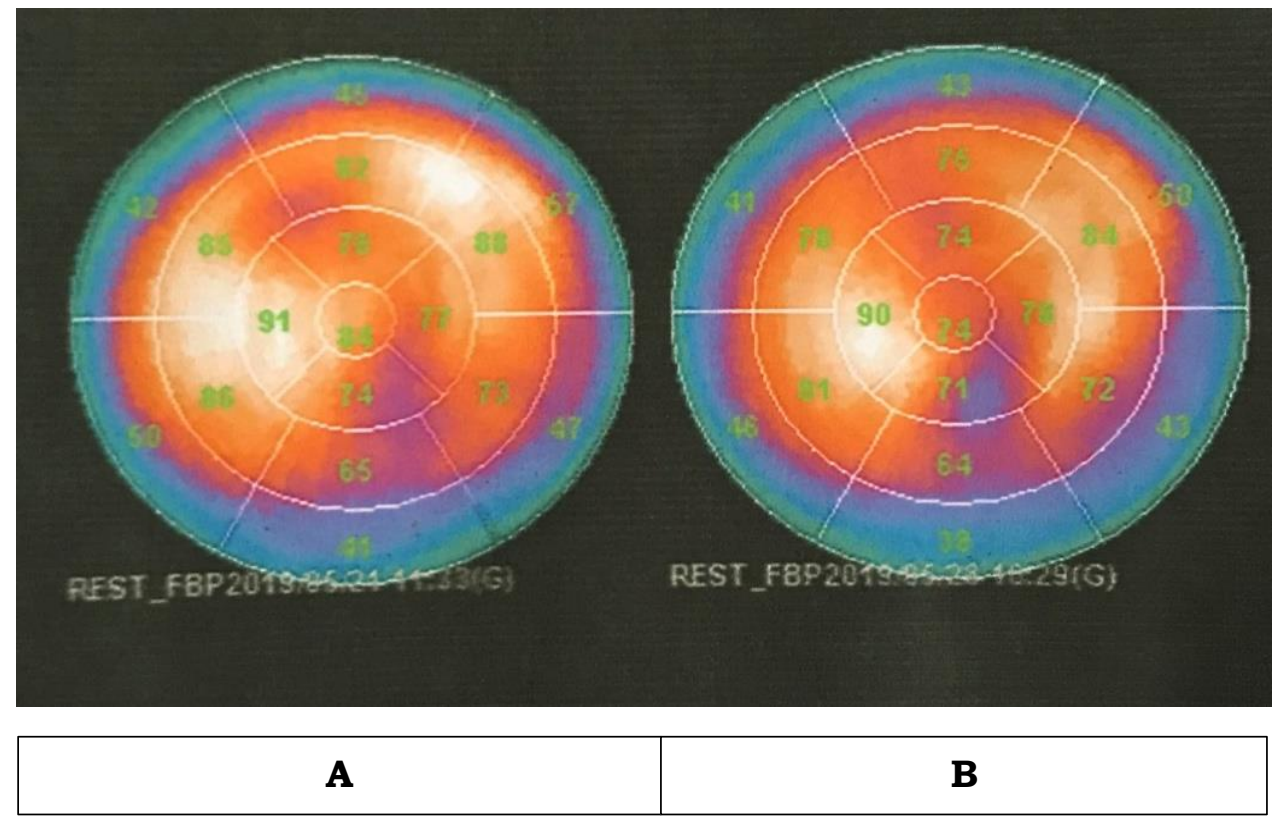

Figure 2. Viability study (VS) images in the patient under routine long-acting nitrates/ nitroglyceryl trinitrate treatment. A: With short-acting nitrate/ISDN $10 \mathrm{mg}$ sublingually, B: Without SAN-added.

\section{Patient III}

A 40-years-old male patient with a diagnosis of ischemic dilated cardiomyopathy and heart failure FC III + Diabetes Mellitus type II. He has a history of coronary heart disease since 2018 and had one cardiac catheterization but was not put on a STENT because of $100 \%$ blockage. He complains of sweating all the time. At the time of examination, the general condition was good. Physical examination showed blood pressure $110 / 80 \mathrm{mmHg}$, heart rate: 70 beats per minute, breathing 20 beats per minute, regular heart rhythm S1-S2, there was no murmur and gallop rhythm as well; normal pulmonary vesicular breath sound.

During the administration of $10 \mathrm{mg}$ short-acting nitrates/ISDN sublingual, blood pressure was monitored every 10 minutes. The patient has experienced dizziness and blood pressure drops to $80 / 60 \mathrm{mmHg}$, while he waits for the imaging procedure. Blood pressure improved to $90 / 70$ $\mathrm{mmHg}$ shortly before the imaging procedure.

The results showed there was no significant difference in perfusion defects between the two images in the evaluation of myocardial viability. (Figure 3). 


\section{Serial Case Reports}

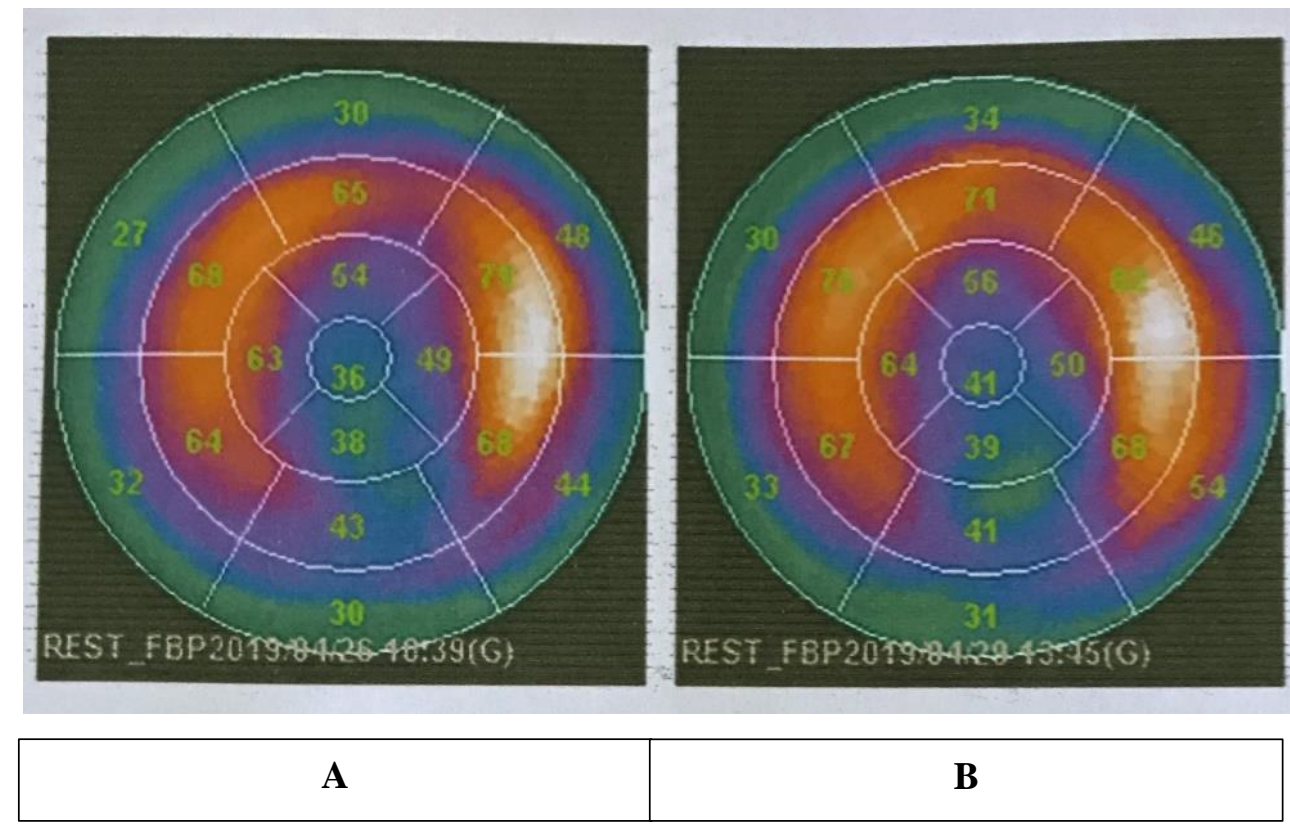

Figure 3. Viability study (VS) images in the patient under routine long-acting nitrates/ nitroglyceryl trinitrate treatment. A: With short-acting nitrate/ISDN $10 \mathrm{mg}$ sublingually, B: Without SAN-added.

\section{Discussion}

Coronary artery disease (CAD) patients with left ventricular dysfunction but viable myocardium have historically benefited from revascularization therapy (RT), if patients have viable myocardium, revascularization can improve heart function and therefore survival; otherwise, patients will do better with medical therapy alone. Myocardial viability study has been proposed as a key factor in the decision-making process concerning coronary revascularization procedures in patients with left ventricular dysfunction and coronary artery disease. ${ }^{1,4}$

Thallium-201 (Tl-201) SPECT imaging is the oldest and most common method of assessing myocardial ischemia. ${ }^{5}$ It is also well established as a means of measuring myocardial viability. Tl-201 has the advantage of entering myocardial cells by active transportation, which increases its accuracy for detecting viable myocardium. For this purpose, two protocols are usually used - stress-redistribution-reinjection and rest-redistribution imaging. While the first is focused on data about stress-induced ischemia and viability, the second focuses only on viability. Tl-201 has some limitations for routine use, due to its longer physical half-life, and relatively low photon energy and flow. This may yield images with low count rates and possible attenuation artifacts and, consequently, suboptimal images. ${ }^{6}$ The sensitivity, specificity, positive predictive value, and negative predictive value of VS using Tl-201 were $85 \%, 60 \%, 65 \%$, and $80 \%{ }^{4}$ 


\section{Serial Case Reports}

Several imaging techniques have been developed to detect myocardial viability. F18FDG PET scan is the most accurate in assessing the likelihood of functional improvement of left ventricular function after coronary revascularization. F18-FDG PET is considered to be the gold standard for determining myocardial viability. The sensitivity, specificity, positive predictive values, and negative predictive values of F18-FDG PET 92\%, 63\%, 77\%, and $85 \%$ respectively. ${ }^{6}$ The availability of PET worldwide, especially for the assessment of myocardial viability, remains severely limited, partly related to cost and training. This issue is relevant to both the developed and the developing world. Currently, using SPECT remains a very viable option. ${ }^{4}$

Several other studies were conducted to evaluate the accuracy of short-acting nitrateadded of myocardial perfusion imaging in prediction recovery of left ventricular function after coronary RT. The diagnostic performance of VS using Tc-99m sestamibi with short-acting nitrate-added showed the sensitivity, specificity, positive predictive values, and negative predictive values of Tc-99m sestamibi $81 \%, 66 \%, 71 \%$, and $77 \% .{ }^{4}$ In several studies, showed that the accuracy of myocardial viability examination using Tc-99m sestamibi/tetrofosmin was less than Tl-201 and lower sensitivity, although they are not as good as Tl-201, radiopharmaceutical labeled Tc-99m has been used as an alternative to Tl-201 for its higher quality combined with lower radiation exposure. ${ }^{3,6}$ One study showed good agreement results of myocardial viability imaging using a short-acting nitrate-added protocol with Tc-99m tetrofosmin as radiopharmaceutical and F18-FDG PET/CT scan. ${ }^{5}$

The uptake and retention of the technetium-based tracers depend on perfusion, cell membrane integrity, and mitochondrial function. In areas of contractile dysfunction, a > 50-60\% tracer uptake on a resting image is frequently used as a marker for viability. It has also to perform Tc-99m sestamibi SPECT after nitrate administration, to increase blood flow and tracer delivery to severely hypoperfused areas. Typically, a resting image and a nitrate-enhanced image are acquired, and a $>10 \%$ increase in tracer uptake on the nitrate-enhanced images is considered indicative of viability. ${ }^{3}$

In the clinical setting, nitrate is divided into organic and inorganic nitrates. Organic nitrates mainly use for the treatment of heart diseases, but inorganic nitrates are rarely used for treatment. The principal effect of both organic and inorganic nitrate is via NO. There are several differences related to their pharmacokinetic and pharmacodynamic properties. ${ }^{7}$

Organic nitrates, such as nitroglyceryl trinitrate, isosorbide dinitrate, and isosorbide mononitrate, are rapidly absorbed in several sites, such as the gastrointestinal tract, mucous membranes, and skin, depending on the preparation. Organic nitrates have several hemodynamic 


\section{Serial Case Reports}

effects which are generally due to vasodilating effects on the veins and arteries. Nitric oxideinduced venous dilation causes a decrease in ventricular load, resulting in decreased myocardial oxygen demand. Nitrates also dilate large and medium-sized coronary arteries and arterioles > 100 micrometers in diameter. This effect reduces systolic pressure on the left ventricle wall by decreasing afterload and decreasing myocardial oxygen demand. The hemodynamic effect of nitrate on the coronary arteries of atherosclerotic patients can also relieve angina. Nitrates dilate the epicardial coronary arteries, including the stenotic segments, and increase blood flow in the coronary collateral vessels by reducing resistance on these collateral vessels. Organic nitrates do not dilate coronary micro artery with a diameter $<100$ micrometers, thus reducing the risk of ischemia due to the coronary steal phenomenon. ${ }^{8}$

Our cases showed no visually significant difference between both images. According to Divakaran et al. Nitroglyceryl trinitrate has a plasma half-life of 1 to 4 minutes; following hepatic and intravascular metabolism, the biologically active metabolites have a half-life of approximately 40 minutes. Isosorbide dinitrate (ISDN) is rapidly absorbed and undergoes extensive first metabolism by the liver, to produce low bioavailability. The slowly released preparation had a slower absorption rate and can provide a therapeutic plasma concentration of the drug for up to 12 hours. Nitric oxide released from the nitrate group is responsible for the mechanism of action of nitrates. Although their differences in terms of their pharmacokinetic and pharmacodynamic properties, nitrates are considered to mediate their effects principally via NO and share similarities. ${ }^{7,8}$ Start from moderate doses, nitrates can also exert significant coronary artery dilation, allowing blood flow to ischemic areas during coronary artery occlusion. ${ }^{9}$

Nitrate is generally well tolerated, with the most common adverse drug effects being dose-dependent headache, flushing, and dizziness due to its vasodilatory effects. In our cases, patients had an experience of blood pressure drop, and fluid infusion was given to reverse the drop of blood pressure, overdosing on sublingual nitrates may lead to postural hypotension. ${ }^{10}$

\section{Conclusions}

In CAD patients with ventricular dysfunction and who should not stop taking long-acting nitrate, VS images might be performed without the need to take additional vasodilator prior to radiopharmaceutical injection. Further study is recommended with a larger number of subjects and using the gold standard for comparison. 


\section{Serial Case Reports}

\section{References}

1. Orlandini A, Castellana N, Pascual A, Botto F, Cecilia Bahit M, Chacon C, et al. Myocardial Viability for Decision-making Concerning Revascularization in Patients with Left Ventricular Dysfunction and Coronary Artery Disease: A Meta-analysis of Non-randomized and Randomized Studies. Int J Cardiol. 2015;182:494-9.

2. Solimana MA SA, Esawyb AS. Assessment of Viable Myocardium by Nitrate-augmented Technetium-99m Sestamibi Myocardial Perfusion Imaging. Menoufia Med J. 2019;32:177-80.

3. Bax JJ, Delgado V. Myocardial Viability as Integral Part of The Diagnostic and Therapeutic Approach to Ischemic Heart Failure. J Nucl Cardiol. 2015;22(2):229-45.

4. Jayadeva PS, Better N. How Viable is SPECT for Viability Assessment in The PET Era? J Nucl Cardiol. 2020.

5. Mylonas I, Beanlands RS. Radionuclide Imaging of Viable Myocardium: Is it Underutilized? Curr Cardiovasc Imaging Rep. 2011;4(3):251-61.

6. Ker WDS, Nunes THP, Nacif MS, Mesquita CT. Practical Implications of Myocardial Viability Studies. Arq Bras Cardiol. 2018;110(3):278-88.

7. Omar SA, Artime E, Webb AJ. A Comparison of Organic and Inorganic Nitrates/Nitrites. Nitric Oxide. 2012;26(4):229-40.

8. Divakaran S, Loscalzo J. The Role of Nitroglycerin and Other Nitrogen Oxides in Cardiovascular Therapeutics. J Am Coll Cardiol. 2017;70(19):2393-410.

9. Lee PM, Gerriets V. Nitrates. In: StatPearls. Treasure Island (FL): StatPearls Publishing; 2021.

10. Boden WE, Padala SK, Cabral KP, Buschmann IR, Sidhu MS. Role of Short-acting Nitroglycerin in The Management of Ischemic Heart Disease. Drug Des Devel Ther. 2015;9:4793-805. 